World Lumen Congress 2021 | May 26-30, 2021 |

Iasi, Romania

\title{
The Dissonance Tourist Demand - Prices. The Evolution of Romanian Tourist Packages to Turkey and Egypt Destination, During the COVID-19 Pandemic
}

Corina Mădălina PINTILEI \& Pavel STANCIU https://doi.org/10.18662/wlc2021/57

How to cite: Pintilei, C.M., \& Stanciu, P. (2021). The Dissonance Tourist Demand - Prices. The Evolution of Romanian Tourist Packages to Turkey and Egypt Destination, During the COVID-19 Pandemic. In A. Sandu (vol. ed.), Lumen Proceedings: Vol. 17 World Lumen Congress 2021 (pp. 559-571). Iasi, Romania: LUMEN Publishing House. https://doi.org/10.18662/wlc2021/57 


\title{
The Dissonance Tourist Demand - Prices. The Evolution of Romanian Tourist Packages to Turkey and Egypt Destination, During the COVID-19 Pandemic
}

\author{
Corina Mădălina PINTILEI ${ }^{1}$, Pavel STANCIU²
}

\begin{abstract}
The travel industry and tourism can rightly be considered the most affected branches of the global economy in the COVID-19 era, the tourism market registering the sharpest post-war decline with significant disruptions to the supply-demand ratio.

An analysis of the tourist offers promoted by two of the most prolific tour operators in Romania states a strategic endurance approach based on psychological prices easily predictable, but focused on regaining a large segment of Romanian tourists who before 2020 practiced outgoing tourism . Turkey and Egypt are considered the destinations of the pandemic moment, the most appreciated in a state of continuous uncertainty, insecurity and reluctance to travel.

During the years 2019-2020, the price offers of the Romanian tour operators did not register major changes, even if the outgoing tourist packages experienced, in full pandemic, conjunctural oscillations with reasonable decreases of prices followed, in some places, by price increases meant to suggest an intensification of tourist consumption with the lifting of the lockdown in various countries and the announcement of the first measures of social relaxation.

The measures regarding the vaccination and the immunization of the population determined the Romanian tourists to react positively to the inner, urgent desire to travel regardless of the effects of the COVID-19 pandemic and the temporary restrictions determined by it.
\end{abstract}

Keywords: Romanian tour operators, Sars-Cov-2, prices, tourist packages, Turkey and Egypt destinations.

\footnotetext{
1 Researcher, Stefan cel Mare University of Suceava, Suceava, Romania, mada pintilei@yahoo.com

2 Associate Professor PhD, Stefan cel Mare University of Suceava, Suceava, Romania, pavelstanciu@,usm.ro
} 


\section{Introduction}

Beyond the speculations of the analysts regarding the tourist circulation and the consumption of stay services of the Romanian citizens, the outgoing activity far exceeds the incoming. Domestic tourism does not excel either, even though tourism authorities and the government have tried to support local consumption by offering holiday vouchers to employees of public institutions.

After more than a year of pandemic, the appetite of Romanian tourists for foreign travel has sharpened compared to the national alternatives. Romanian tourists want to spend their holidays abroad, foreign destinations thus gaining more ground in front of local resorts, a consumer outlook felt since 2018-2019, before the epidemiological crisis caused by COVID-19 / Sars-CoV-2, Bulgaria, Egypt, Turkey and Greece remain, in the top of the preferences of Romanian tourists. (Diaconu, 2021; WallStreet, 2017)

Regarding the share of Romanian tourists who practiced outgoing tourism, it experienced a significant decrease in 2020, mainly due to the epidemiological crisis.

If for 2019, out of the almost 2 million tourists who benefited from the services of travel agencies, $46 \%$ of them preferred to spend their holidays outside the country, most of them being interested in the circumediterranean area and the Bulgarian coast, for 2020, the share of outgoing and implicitly the number of tourists decreased to $34 \%$ from a number of 807 thousand tourists registered in the statistics of travel agencies in Romania. (National Institute of Statistics, 2021) Compared to 2019, in 2020 there was a decrease of only $12 \%$, the number of Romanian tourists who purchased outgoing tourist packages from organizing travel agencies, a positive aspect given the unpredictable travel conditions of the pandemic year, more chosen that, according to UNWTO projections, travel estimates were based on a halving of international tourist flows (Richter, 2021). For the entire period, the highest percentages of tourists who have opted for foreign destinations are focused on destinations in countries such as Turkey, Egypt, Bulgaria, Greece, Italy, United Arab Emirates.

At the same time, Romanian tourists attracted by SSS destinations (Sea, Sand, Sun) carefully followed the regional incidence of cases and the global evolution of the COVID-19 pandemic without completely giving up the pleasure of traveling. Depending on the situation and in accordance with multinational travel policies, the attention of Romanian tourists has shifted to exotic and / or eccentric destinations less affected by the pandemic, with 
a more relaxed policy, such as: Dubai, Maldives, Mexico, Dominican Republic or Zanzibar. This situation was a consequence of the fact that, from the activation of the "conservation instinct", tour operators tried to reinvent themselves, meeting allocentric tourists (willing to risk, "missionaries" or "kamikazes") with versatile options as their expectations.

It is interesting that, according to the largest tour operator in Romania, over $35 \%$ of all tourists who purchased summer vacation packages also concluded cancellation insurance policies, as an additional safety measure. (Voinea, 2020)

These assertions were the basis for starting this analysis aimed at quantifying at least partially the resizing of the national outgoing sector, the decrease in tourism demand in the context of the Sars-CoV-2 epidemic crisis, a situation which inevitably required substantial changes in the marketing policy of tourism operators. The generic objectives aimed at identifying and exemplifying the prices applied to tourist packages in 2020, through a marketing analysis based on the typology and price fluctuation; price aggregators in tourism, tariff policies and optimization of pricing strategies in the hospitality industry.

Therefore, the analysis of the dissonance between supply and demand (price) for packages and tourist services with broadcast addressability explains what summer destinations in Turkey and Egypt, is a study to present information and analysis of specific diagnoses in terms of tourist purchases for stays SSS, changes in consumer preferences for the two destinations.

\section{Demand and Supply Price in Tourism. Theoretical Aspects}

From an economic perspective, the tourist demand is represented by all the people who intend to travel and takes into account the amount of tourist goods and services, materialized in tourist packages, which can be purchased in a limited area, at a certain price and in a certain period, being influenced by the motivation and behavior of tourists. The solvent demand of the population for the tourist products offered by the market materializes in the form of tourist consumption. So, in a broad sense, it involves all the expenses incurred by the customer at the time of the decision to buy the package basic services and associated services (we can talk, as appropriate, airport-hotel transfer, rent-a-car, health insurance, Storno insurance, etc.) to which are added a series of more or less spontaneous requests such as optional excursions, ordering drinks at the beach, requesting access to the hammam, massage, room service, etc. The manifestation of the demand 
takes place in an invariable number of variants, nuanced from one tourist to another, according to certain criteria difficult to quantify accurately. (Richter, 2021) The real motivations that target the tourist and his preferences towards the attractions offered by the destinations; socio-professional typology, family point of view; its financial resources and the technical characteristics of the trip made (length of stay, forms of transport, accommodation) being the most common. (Nedelea, 2008)

Compared to other areas, the tourist demand presents a series of particularities that occur depending on the specifics of the services that are part of the tourism products consumed in the market. Among the characteristics of the demand for tourist services are the high degree of mobility, with relatively rapid changes from a quantitative and structural point of view and with changes registered under the impulse of a multitude of objective and subjective factors. The determination of the high degree of mobility also takes place depending on the rigid character of the offer;

At the same time, the tourist demand is very elastic depending on the modification of the influencing factors and can be determined by a comprehensive set of psycho-socio-economic factors, such as: the income level of the population; the quota intended for tourist consumption; the level of tourist services tariffs; share of free time; degree of culture. (Stancioiu, 2004)

The performance of marketing policies is reflected in the way in which the price is oriented by the company, as a means of making a profit, the price being conceived as a vital element in the positioning of the product. Regarding the decision-making process of pricing (Kotler and Lee (2012) and (Dibb et all. (2012) highlight a number of factors that affect price decisions as:

- Internal factors: organizational and marketing objectives; price targets; marketing strategy; the costs; other variables of the marketing mix;

- External factors: estimated demand; competition; buyer perception; members of the marketing channel.

The specificity of pricing and tariff policy in the tourism industry is focused on the characteristics of services and their influence on market value in a diachronic approach given by the duality management - marketing (Cowell, 1984; Middleton, 2012). 
Table 1. The characteristics of tourist services and their influence on the prices of tourist packages

\begin{tabular}{|c|c|}
\hline Cowell & Middleton \\
\hline $\begin{array}{l}\text { - The perishability of the services } \\
\text { requires the adaptation of the price } \\
\text { in order to meet the fluctuation of } \\
\text { the demand, thus eliminating its } \\
\text { total loss; A better correlation of } \\
\text { supply with demand is required; } \\
\text { The consumer may delay or cancel } \\
\text { the usefulness of a service, } \\
\text { sometimes even having the } \\
\text { opportunity to perform it, which } \\
\text { leads to intense competition } \\
\text { between service providers; } \\
\text { The intangibility of services has } \\
\text { several implications on price; The } \\
\text { higher the share of materials in the } \\
\text { value of services, the greater the } \\
\text { tendency to standardize them and } \\
\text { thus reach a negotiation of prices } \\
\text { between buyer and seller; } \\
\text { The more competitive the price, the } \\
\text { more homogeneous the services; } \\
\text { The inseparability of the services } \\
\text { from the person who provides } \\
\text { them, sets limits on the market } \\
\text { served. }\end{array}$ & $\begin{array}{l}\text { - The high price elasticity for tourist services } \\
\text { is determined by substitutability; } \\
\text { The long time for booking and setting the } \\
\text { price of tourist services and their } \\
\text { consumption, determines the promotional } \\
\text { prices practiced in the off-season, such as } \\
\text { those related to Early Booking packages; } \\
\text { The impossibility of storing the tourist } \\
\text { services imposes the non-division of risks } \\
\text { between the organizing and the } \\
\text { intermediate agencies; } \\
\text { Unpredictability of tourist service prices, } \\
\text { except for short-term fluctuating cost } \\
\text { elements; } \\
\text { The tactical reduction of the price by the } \\
\text { competition in case the supply exceeds the } \\
\text { demand represents a price strategy that } \\
\text { determines the decrease of the demand; } \\
\text { The high degree of psychological } \\
\text { involvement of the consumer, especially in } \\
\text { the case of holiday packages, whose price } \\
\text { represents the symbol of his social position } \\
\text { is a favorable factor for maintaining } \\
\text { consumption, at prices above the market } \\
\text { level; } \\
\text { The high vulnerability of demand change } \\
\text { caused by unforeseen economic and } \\
\text { political events can materialize in effects } \\
\text { with a major impact on pricing strategies: } \\
\text { Sars-CoV-2. }\end{array}$ \\
\hline
\end{tabular}

Adaptation by: Middleton V.T.C., Clarke, J.R., (2012). Marketing in Travel and Tourism, Editura Taylor \& Francis, pp. 41-48; 264; 147-148.

All these characteristics confirm the complexity of price decisions for tourism products that are dependent on both market variables, demand and supply, the price being used both as a strategic weapon and as a basic calibration element in the marketing process. (Kotler, 2006) 


\section{The Influence of the Effects of Sars-Cov-2 Epidemiological Crisis on the Activity of Tour Operators in Romania}

The research approach focused on two of the most representative tour operators (TO) in Romania, Paralela 45 and Eximtur, organizing travel agencies operating in the tourism and travel industry for over 30 years, the first TO being established in 1990, and the the second in 1993. Currently, Paralela 45 operates in 8 offices and 14 franchised partners, and Eximtur in over 7 offices located in several cities in Romania: Cluj-Napoca, Bucharest, Timisoara, Sibiu, Suceava.

For reasons related to data confidentiality, we will resort to anonymizing the names for the two tourist units included in the analysis, so that for Parallel 45 we will use TO.1, and for Eximtur we will go for TO.2. The acronyms I opted for follow the logic of the year of the establishment of the two companies.

The first effects of the epidemiological crisis had repercussions, as expected and absolutely naturally, in a resizing of the number of tourist units - branches and partners - that continue to operate on the tourist market. Both operators owned in 2019 an almost double number of units that sold tourist packages. The CEO of TO.1 told the economic newspaper Ziarul Financiar that the considerable decrease in sales of tourist packages in 2020 had the effect of decreasing the specific activity by up to $90 \%$ in some outlets, which required some adjustments and reorganizations of staff. The economic and pandemic context forced the closure of 11 jobs and the dismissal of 105 jobs. (List of Romanian companies, 2021). On the other hand, TO. 2 closed 8 offices, many of them in medium and large cities, but with recognized potential in terms of consumption of outgoing tourist packages such as Suceava, Sibiu or Oradea. (Diaconu, 2020). The most affected workplaces were located in malls and large shopping malls, where the pressure of high rents imposed, where a renegotiation of long-term contracts was rigid, a rethinking of strategic options or even withdrawals from the competitive environment.

According to official data on the economic situation of major tour operators in Romania, there is a more than obvious decline in economic activity, the financial results recording negative figures in terms of profit in the financial year 2020. For the pandemic year 2020 (at a rate average currency 1 Euro $=4.8371$ lei, according to BNR), TO.1 registered a turnover of 35,743,070 lei, that is 7,389,359.33 Euro, well above TO.2 which had a turnover of only 9,364,520 lei, that is 1,935 .978.16 Euro. Although the turnovers are disproportionate, the net loss of over 3 million lei (over 600,000 Euros) in both situations, outlines the magnitude of a year lost from 
almost all points of view. The perverse effects of the pandemic are very serious for TO.1, and for TO.2 they are catastrophic, especially given that the elimination of holiday vouchers from the domestic tourist flow (starting with 2021) exacerbates the financial problems even more.

Table 2. Financial data of the most listed organizing travel agencies in Romania

\begin{tabular}{|c|c|c|c|c|c|c|}
\hline & & TO.1 & & & TO.2 & \\
\hline Year & Turnover & Net Profit & Employees & Turnover & Net Profit & Employees \\
\hline 2020 & $35,743,070$ & $-3,834,117$ & 134 & $9,364,520$ & $-3,106,873$ & 132 \\
\hline 2019 & $53,602,838$ & $3,597,050$ & 239 & $26,408,838$ & $3,867,480$ & 179 \\
\hline 2018 & $45,136,507$ & $3,192,047$ & 229 & $23,798,288$ & $1,799,020$ & 171 \\
\hline 2017 & $37,069,613$ & $2,798,683$ & 224 & $20,840,041$ & $1,738,946$ & 151 \\
\hline 2016 & $32,663,348$ & $2,169,805$ & 196 & $18,148,837$ & $1,671,184$ & 144 \\
\hline 2015 & $29,193,341$ & $2,591,383$ & 187 & $15,754,213$ & $1,251,320$ & 143 \\
\hline 2014 & $26,552,223$ & $1,851,001$ & 186 & $175,266,662$ & $1,121,605$ & 134 \\
\hline 2013 & $24,953,262$ & $1,401,066$ & 175 & $160,077,635$ & $1,407,514$ & 130 \\
\hline 2012 & $127,566,375$ & $1,699,806$ & 200 & $157,059,208$ & $1,766,597$ & 129 \\
\hline 2011 & $27,446,458$ & $1,751,609$ & 191 & $135,400,285$ & $1,753,350$ & 132 \\
\hline
\end{tabular}

Source: List of companies in Romania, https://www.listafirme.ro/search.asp

The amounts registered among the agencie turnover are due to the financial turnovers that started to appear with the exit from the alert state established at the end of the first quarter of the previous year. If in the summer of the previous year, tourists were still reluctant to travel to foreign destinations, starting with September, more and more Romanian tourists began to opt for Last Minute offers in destinations such as Bulgaria, Egypt or Turkey.

Amid the escalation of the epidemiological crisis and the desire to maintain and maintain close relations with customers who have purchased Early Booking offers, tour operators have been forced to propose options for rescheduling pre-contracted tour packages between November 2019 and May 2020 for its summer 2021 with a series of conditions, the most important of which was to keep the period and the accommodation option initially chosen. 


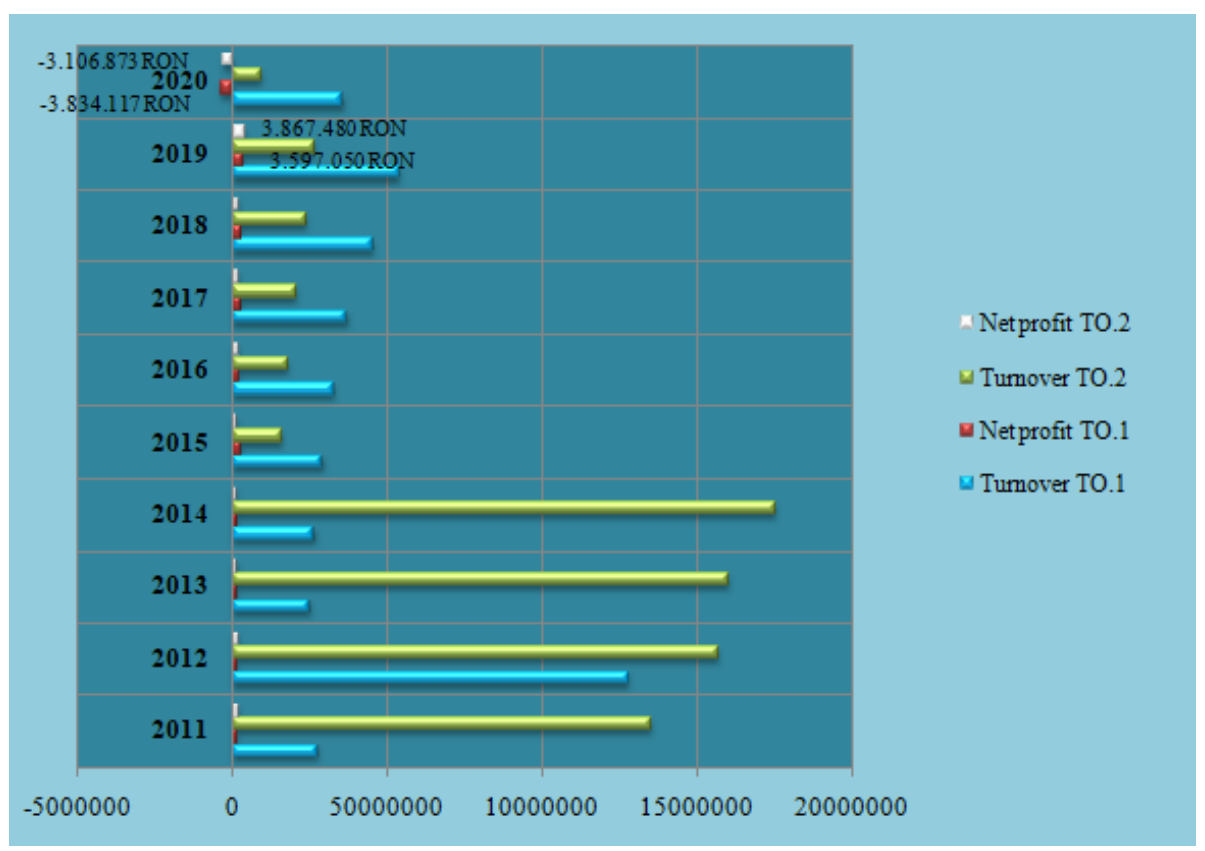

Figura 1. The financial evolution of the most famous organizing travel agencies in Romania.

Source: Processing according to List of companies in Romania, https://www.listafirme.ro/search.asp [accessed on 28.05.2021].

The decline of the agencies' activities is also evident from the perspective of human resources - work pressure, stress, uncertainty and pressure generated by dissatisfied tourists, the managers of the two TOs being forced to lay off or send technically unemployed some of the employees. If in 2019 TO.2 had 132 employees, at the end of 2020 their number decreased by about $25 \%$. TO.1, on the other hand, underwent much more significant changes in the organizational structure which culminated in a decrease in the number of employees by almost $45 \%$.

Workplace burnout, especially in the front office of travel agencies, is a factor that exacerbates the specialized labor crisis in tourism organizations. The great stress and responsibility that employees have to face can be reflected in the medium and long term policy of tour operators.

TO. 2 had to reimburse tourists about 9 million lei, in the context in which May and June 2020 was noted by an influx of requests to cancel the holidays. On the other hand, the year 2021 started with an increase in the appetite of tourists for holidays and stays abroad, a trend that is becoming more pronounced with the start of the summer season. The measures regarding vaccination and immunization of the population, determine the 
Romanian tourists to be again active and more receptive to the new wave of offers, especially since the medical insurances and STORNO cover also the financial losses caused by the cancellation of the trip or the illness with SarsCoV-2 virus. Such facilities become services included in the price of the tourist package, without the tourist being subject to the payment of an additional amount for these services.

Surprisingly, although it was expected that Early Booking packages would no longer be in high demand, the agencies' marketing strategies continued to market Early Booking packages, and tourists still chose to book holidays for this summer in recent months. of 2020, benefiting from discounts of up to $50 \%$. As a consequence, Antalya, Bodrum, Crete, Rhodes, Tenerife, Bulgaria, Greece remain favorite destinations for Romanian tourists. (Economica, 2020)

\section{The Evolution of Romanian Tourist Packages to Turkey and Egypt Destination}

The analysis of the prices practiced by the travel agencies in the pandemic year, as well as in the following years, is a subject of controversy among the tourism enthusiasts (Ziua de cluj, 2021). According to the price offers of the tourist packages that were promoted during the years 20192020, we can say that their prices felt considerable reductions during the "quasi-generalized" lockdown period or the first part of the PCR test period coronavirus / anti-COVID-19 vaccine .

Given the theory of supply and demand elasticity, in the context of the epidemiological crisis, this was no longer valid. Although the demand for tourist packages decreased significantly, the prices of the packages offered did not increase in inverse proportion to their demand. Specifically, taking into account an example for the tourist destination Turkey, in 2019, TO.1 offered a stay of 6 nights / All inclusive, with all related tourist services included, for one person, in high season, at a resort of $5 *$, Aydinbey Famous Resort in Belek resort, at a starting price of 610 euro / person, in Early Booking mode. Under the same conditions, at the same resort, in the pandemic year (2020) the prices started from 607 euro / person, only in Last Minute regime. For the destination Egypt, Hurghada, Hotel Albatros Aqua Park $4 *$, the same operator offers in 2019 a tourist package starting with 475 euro / person, and in 2020 the prices have succumbed to 452 euro / person.

Analyzing the prices of tourist offers for the 2021 season, we notice that in the immediate period, tour operators come to meet tourists with offers worthy of relaunching the tourism industry, considering that prices 
have not expanded since this year, but only varied slightly depending of periods, destination, demand, the opening of tourist markets (especially the ex-Soviet space) and the limitations imposed by the authorities in the country of destination.

For destinations in Turkey and Egypt, the tourist offers available in the $\mathrm{B} 2 \mathrm{C}$ area of the tour operators' agencies, TO.1 and TO.2 are broadly included in the area of a 7-night stay, in All Inclusive / Ultra All Inclusive regime, resort classified with $4-5 *$, for 2 PAX adults and one or two children, with all the related complementary services - charter flight from Bucharest / Iasi / Cluj-Napoca / Timisoara. The analysis followed two consecutive periods to capture the evolution of price offers (Wall-Street, 2017).

Table 3. Prices charged by tour agencies for tour packages for tourists choosing Turkey and Egypt. Author's own conception

\begin{tabular}{lllllc}
\hline 2021 & & $03.07 .2021-10.07 .2021$ & \multicolumn{2}{l}{$07.08 .2021-14.08 .2021$} \\
\hline Season / Tourist package price & TO.1 & TO.2 & TO.1 & TO.2 \\
Turkey & Belek - Granada Luxury Belek & $1.756 €$ & $1.666 €$ & $2.224 €$ & $2.224 €$ \\
& Bodrum - Voyage Bodrum Hotel & $2.616 €$ & $2.596 €$ & $2.566 €$ & $2.566 €$ \\
\multirow{2}{*}{ Egypt } & Hurghada - Sunrise Holidays & $1.240 €$ & $1.111 €$ & $1.240 €$ & $1.164 €$ \\
& Sharm el Sheikh - Steigenberger & $2.396 €$ & $2.338 €$ & $2.452 €$ & $2.458 €$ \\
& Alcazar & & & & \\
\hline
\end{tabular}

Thus, we notice that the prices of tourist packages for the destination Belek, in Turkey increase by up to $25 \%$, the TO.2 agency practicing a higher price by up to 558 euros / tourist package compared to TO.1, which moderates the growth limiting it to $20 \%$. TO. 2 also offers a higher price for packages for Sharm el Sheikh resort, for which the price increases by a double amount compared to TO.1. In some cases the prices remain constant, or register small reductions in amounts of 30-50 euros / tourist package. Therefore, based on the data below, as well as information provided by travel agencies, we find that Turkey sells more expensive travel packages, both to Belek and Bodrum, while Egypt still offers tourists the opportunity to travel and enjoy a one-week stay at much more affordable prices but with a much higher price fluctuation. The destination Egypt also attracts with its much heavier historical load compared to Turkey.

The prices of the information on the evolution of outgoing tourist packages show that the repercussions of the epidemiological crisis have dissipated against the background of tourists' desire to travel, especially since 
this year, but also due to the fact that they have been introduced a behavior oriented towards a consumption.

\section{Conclusions}

In the case of both Turkey and Egypt, hoteliers practice approximately the same range of services. Turkey imposes a much stricter distancing and observance of protection and prevention rules, while in the case of Egypt we are dealing with a greater degree of relativization. Although for Turkey, tour operators were forced to increase prices by up to $25-35 \%$, for Egypt instead prices increased by only about $10 \%$.

Although the comfort class seems to be slightly different, for Turkey and Egypt the price offers have become competitive among all travel agencies (Institutul National de Statistica, 2021), precisely due to the very high demand, which did not take long to appear immediately after the opening of borders and the constant lifting of restrictions. In this sense, travel service providers and organizing agencies have resorted to adjustments to package prices, but additions to certain package tours seem justified, referring to considerations such as: financial restructuring of travel agencies and service providers, increase the prices of resources needed in the process of providing tourist services, the transition from market penetration prices, in the case of Egypt, to market prices, and then to competitive prices, given that Egypt has begun to attract a significant number of tourists, starting with 2019. At the same time, regarding the elements that determine the offer of more expensive packages, we must keep in mind that in the case of accommodation units and transport companies the operating costs have increased because they have to allocate a budget and for measures to protect and prevent the spread of the Sars-CoV-2 virus. In order to provide safety, quality and comfort to tourists, these things are absolutely necessary. In addition to all this, the tour operators resorted to the inclusion of medical insurance in the tourist package.

Through the marketing analysis of the prices applied to the outgoing tourist packages for the destinations Egypt and Turkey, season 2021, we understand that the psychological pricing strategy seems to be the most appropriate, at the same time being enhanced by the market value and prestige of the tour operator. The most eloquent example in this regard is focused on the pricing policy applied to tourist packages in Belek, Bodrum and Sharm el Sheikh, offered by TO.1 and TO.2 and based on middle prices that march on the quality of services doubled by the guarantee of compliance community prevention and social distancing. In the case of the 
destination Hurghada - Egypt - we are talking more about a market development policy supported for the time being on penetration prices. Analyzing the reality of the tourism industry, in terms of price indicators of the hospitality and travel industry, we remain of the opinion that the attractiveness of the two markets is dependent on price volatility in relation to the reactive measures of the authorities against the Sars-CoV-2 pandemic.

Given that the current period the travel agencies have revitalized their activity and feel constant increases in tourist demand compared to summer destinations in Turkey and Egypt, we conclude that they remain the star destinations of Romanian outgoing, even after this prolonged epidemiological crisis.

\section{References}

Cowell, D. W. (1984). Marketing of services. Heinemann Publishing House.

Diaconu, M. (2020). In perioada aprilie - iulie 2020 an incetat activitatea 26 de agenții de turism, față de doar donă agenții închise în aceeaşi perioadă a anului trecut [Between April and July 2020, 26 travel agencies ceased their activity, compared to only two agencies closed in the same period last year]. Ziarul Financiar [Finance newspaper]. https://www.zf.ro/companii/in-perioada-aprilieiulie-2020-au-incetat-activitatea-26-de-agentii-19525899

Diaconu, M. (2021). Turişstii români vor să îşi petreacă Paștele in străinătate, destinațiile externe câștigă teren in fața stațiunilor locale: Egiptul, Turcia şi Grecia sunt în topul preferintelor [Romanian tourists want to spend Easter abroad, foreign destinations are gaining ground in front of local resorts: Egypt, Turkey and Greece are in the top of preferences]. Business Magazin. https://www.businessmagazin.ro/actualitate/turistii-romani-vor-sa-isipetreaca-pastele-in-strainatate-20036915

Dibb, S., Simkin, L., \& William, M. (2012). Marketing: Concepts and Strategies (6th ed.). Houghton Mifflin.

Kotler, P. (2006). Marketing management. Publishing house Teora.

Kotler, P., \& Lee, N. (2012). Social marketing: Influencing Behaviors for Good, (4th Ed.). Social Marketing Services. www.socialmarketingservice.com

Middleton, V. T. C., \& Clarke, J. R. (2012). Marketing in Travel and Tourism. Taylor \& Francis Publishing House.

Nedelea, A. (2008). Marketing policies. Didactic and Pedagogical Publishing House.

Richter, F. (2021). COVID - 19's Crushing Impact on International Tourism. Statista. https://www.statista.com/chart/22691/effect-of-the-pandemic-oninternational-tourist-arrivals /

Stăncioiu, A. F. (2004). Marketing strategies in tourism. Economic Publishing House. 
Voinea, O. (2020). Efectul coronavirus: vacanțe în destinații cu temperaturi peste $25^{\circ} \mathrm{C}$ [Coronavirus effect: holidays in destinations with temperatures above $\left.25^{\circ} \mathrm{C}\right]$. Biz. https://www.revistabiz.ro/efectul-coronavirus-vacante-indestinatii-cu-temperaturi-peste-25c/

Institutul National de Statistica. (2021). Actiunile turistice organizate de agentiile de turism in anul 2020 [Tourist actions organized by travel agencies in 2020]. Institutul National de statistica [National Institute of statistics]. https://insse.ro/cms/sites/default/files/field/publicatii/actiunile turistice organizate de agentiile de turism 2020.pdf

Economica. (2020). Veștile despre vaccinurile anti-Covid dau încredere românilor să călătorească [News about Covid vaccines gives Romanians confidence to travel]. Economica.net.

https://www.google.com/search?q=google+translate\&rlz=1C1CAFA en $\underline{\mathrm{RO} 775 \mathrm{RO} 775 \& \mathrm{oq}=\text { goo\&aqs }=\text { chrome } .2 .69 \mathrm{i} 59 \mathrm{j} 46 \mathrm{i} 39 \mathrm{i} 199 \mathrm{i} 465 \mathrm{j} 69 \mathrm{i} 59 \mathrm{j} 69 \mathrm{i} 57 \mathrm{j} 0}$ i6712j69i6012.2327j0j7\&sourceid $=$ chrome\&ie $=U$ UTF-8

Wall-Street. (2017). Cat de atractiva mai este Turcia pentru turistii romani [How attractive is Turkey to Romanian tourists]. Wall-street.ro. https://www.wallstreet.ro/articol/Lifestyle/216901/cat-de-atractiva-mai-este-turcia-pentruturistii-romani.html\#gref

Ziua de cluj. (2021). Pandemia a "furat" Eximtur donă treimi din afacere [The pandemic "stole" Eximtur two-thirds of the business]. Ziua de Cluj [Cluj day]. https://zcj.ro/economie/pandemia-a-furat-eximtur-doua-treimi-dinafacere--215819.html

Listafirme. (2021). Lista Firmelor Din România [List Of Companies In Romania]. LF. https://www.listafirme.ro/pagini/p2021.htm 